Agnieszka Lewicka-Zelent

Uniwersytet Marii Curie-

-Skłodowskiej w Lublinie

Sylwia Huczuk

Koło Naukowe Twórczych

Pedagogów Resocjalizujących,

Uniwersytet Marii Curie-

-Skłodowskiej w Lublinie
Kiedy myślimy Rodzina..., red. M. Duda, K. Kutek-Sładek, Kraków 2016, s. 457-474 (Praca Socjalna w Teorii i Działaniu, 2).

DOI: http://dx.doi.org/10.15633/9788374385091.32

\title{
Wsparcie dziecka w sytuacji rozwodu rodziców
}

\author{
Support your child in case of parents' divorce
}

\begin{abstract}
The parents' divorce constitutes a threat to the mental, emotional and social development of the child. Research done hitherto points to direct and deferred negative consequences of divorce for all family members, especially the youngest ones, susceptible to the influence of others - the children. This difficult crisis situation is reflected in the behaviour of the adults who are experiencing it. Adult children of divorcing parents frequently live with the stigma of a child who is rejected and unloved. As a result, they function abnormally in families of their own. It is therefore important to provide special support for the children whose parents have decided to divorce. Family mediation is a good opportunity to set-
\end{abstract}

tle the material and social situation of these families. Mediation meetings can help parents realize the mistakes they make which arise from very high levels of negative emotions resulting from the break-up. This article aims to show the effects of the parents' divorce on the children and to show specific ways to assist them in overcoming this crisis situation. One of the suggestions of support is the use of therapeutic fairy tales to explain to children the new family situation in which they find themselves. Proceeding from this assumption, the authors of the article decided to gather the opinions of parents and their children about fairy tales about divorce. For this purpose we have employed a questionnaire of our own as well as fairy 
tales written for children of divorcing parents.
Keywords: support, children, divorce, therapeutic fairy tales, mediation

Według Heleny Izdebskiej rodzina: „,stanowi środowisko życia dziecka, z którym jest ono związane biologicznie, uczuciowo, kulturowo, materialnie i prawnie"'. Jest naturalną grupą, która opiera się na związkach krwi, małżeństwa oraz wspólnoty oraz związkach o charakterze prawno-ekonomicznym² ${ }^{2}$ Jako podstawowa komórka społeczna pełni następujące funkcje: prokreacyjną, produkcyjną, socjalizacyjną, usługowo-opiekuńczą oraz psychohigieniczną. Funkcja prokreacyjna polega na wydawaniu przez rodziców potomstwa na świat. Funkcja produkcyjna dotyczy dostarczania społeczeństwu nowych przyszłych pracowników, a socjalizacyjna - kształtowania osobowości dziecka, a także przygotowywania go do życia w społeczeństwie i właściwego pełnienia ról społecznych poprzez przekazywanie odpowiednich wzorców oraz norm zachowań akceptowanych społecznie. Funkcja usługowo-opiekuńcza polega na zapewnianiu opieki oraz pomocy tym członkom rodziny, którzy jej wymagają, głównie w sytuacjach ciężkich chorób, niepełnosprawności itp. Funkcja psychohigieniczna służy zapewnieniu członkom rodziny podstawowych potrzeb, takich jak: bezpieczeństwo, stabilizacja, wsparcie emocjonalne, miłość, a także stwarza odpowiednie warunki dla rozwoju osobowości ${ }^{3}$.

W sytuacji rozwodu poszczególne funkcje rodziny, które powinna ona spełniać, ulegają degradacji. Nie jest możliwe powiększanie jej w momencie, gdy małżeństwo przestaje istnieć, a małżonkowie nie mieszkają ze sobą. Rozwód rodziców zaburza proces socjalizacji dziecka. Uczenie potomstwa pełnienia określonych ról społecznych, kształtowanie jego osobowości i postaw wobec innych osób odnosi największe rezultaty w momencie, gdy odbywa się na zasadzie współpracy obojga rodziców. W sytuacji gdy wychowaniem dziecka zajmuje się jeden rodzic, młody człowiek może okazywać niechęć w stosunku do tego rodzica, który opuszcza dom ${ }^{4}$. Może również czynnie przeciwstawiać się normom społecznym, izolować się, okazywać nieposłuszeństwo wobec rodziców lub przesadnie zwracać na siebie uwagę. Rozstanie rodziców skutkuje tym, że opieka nad dzieckiem sprawowana jest przez jednego z rodziców. Praca zawodowa i życie prywatne całkowicie wypełniają jego czas, podczas gdy dziecko

1 H. Izdebska, Wyższość rodzinny nad innymi środowiskami wychowawczymi, „Problemy Opiekuńczo-Wychowawcze" 1 (1989), s. 3.

2 Z. Zaborowski, O rodzinie. Rodzina jako grupa społeczno-wychowawcza, Warszawa 1969, s. 22.

3 W. Okoń, Nowy słownik pedagogiczny, Warszawa 1998, s. 336.

4 J. Wilk, Pedagogika rodziny. Zagadnienia wybrane, Lublin 2002, s. 46, 88-89. 
niejednokrotnie pozostaje same. Nie otrzymuje ono wystarczającego wsparcia oraz nie jest dostatecznie diagnozowane, co stanowi podstawowy brak w procesie udzielania mu efektywnej pomocy.

W sytuacji rozwodu w rodzinie następuje także deprywacja podstawowych potrzeb dziecka. Nie czuje się ono bezpiecznie oraz nie ma poczucia stabilizacji i wsparcia w rodzicach. Staje się chwiejne emocjonalnie, w rezultacie czego zostaje zaburzony jego rozwój w sferze psychospołecznej i fizycznej ${ }^{5}$.

\section{Radzenie sobie przez dzieci z rozwodem rodziców}

Według Judith Wallerstein ${ }^{6}$ dzieci rozwodzących się rodziców mierzą się z tą kryzysową dla nich sytuacją przez co najmniej kilkanaście lat. Proces, w którym uczestniczą, przebiega według pewnych faz, występujących w określonej kolejności. W pierwszym etapie, który trwa do roku po rozstaniu rodziców, dzieci mają problem z przystosowaniem się do nowej sytuacji, dlatego często odczuwają bezradność. Przez kolejne półtora roku próbują funkcjonować tak jak wtedy, gdy rodzina była pełna. Podejmują próbę dystansowania się od nowych problemów, stopniowo powracając do wykonywania czynności, które w niedalekiej przeszłości były dla nich rutynowe. Przez kolejne lata przyzwyczajają się do obecności w swoim życiu tylko jednego rodzica i braku drugiego, który do niedawna pełnił określone role w domu i zajmował stałą pozycję $\mathrm{w}$ rodzinie. W następstwie poczucia niższości postrzegają siebie nieadekwatnie. Następne lata upływają im między innymi na walce ze swoimi negatywnymi emocjami, szczególnie złością i poczuciem winy z powodu odejścia rodzica. W końcu doświadczają poczucia wolności i ulgi, gdyż godzą się w subiektywny, optymalny dla siebie sposób z rozstaniem rodziców. Akceptacja (a może tylko tolerancja) tej sytuacji umożliwia im angażowanie się we własne związki w sposób dojrzały i świadomy.

Pogodzenie się z rozstaniem rodziców może zająć dzieciom wiele lat. Niemniej jednak proces przystosowania się do nowej sytuacji przebiegnie szybciej, gdy mniej konfliktów będzie pomiędzy rodzicami oraz gdy będą oni współpracowali ze sobą dla dobra dzieci. Szczególnie trudne dla starszych dzieci może być zaadaptowanie się do sytuacji, w której rodzice postanawiają zało-

5 M. Ziemska, Rodzina a obecność, Warszawa 1977, s. 165.

6 M. Farnicka, Sposoby radzenia sobie $z$ rozwodem przez dzieci, „Wychowanie na co Dzień" 3 (2000), s. 19n. 
żyć nowe rodziny. Jednakże Urszula Sokal ${ }^{7}$ dowodzi, że rekonstrukcja rodzin może sprzyjać budowaniu bardziej pozytywnych relacji z rodzicami po rozwodzie. Oznacza to, że rozwód traktowany jest jako kryzys otwierający nowe możliwości przed wszystkimi członkami rodziny, którzy doświadczają pewnej metamorfozy i zmian życiowych (także tych pozytywnych) ${ }^{8}$.

\section{Wpływ rozwodu rodziców na przyszłość dzieci}

Rozwód jest na tyle traumatyczną sytuacją dla dzieci, że najczęściej pozostawia swoje piętno i daje o sobie znać w dorosłym życiu9. Jak twierdzą Barbara M. Kaja i Anna W. Wróblewska ${ }^{10}$, podobieństwo przeżywanych przez dzieci doświadczeń związanych z rozstaniem rodziców może wywoływać u nich takie same skutki - określane jako przemijający syndrom rozwodowy. Autorki opracowały listę cech często opisywanych przez osoby, których rodzice postanowili się rozstać. Uważają, że odczuwają one bezradność i lęk przed popełnieniem błędów rodziców oraz porażką we własnym życiu, szczególnie w związkach. Bywają niecierpliwe i nadmiernie odpowiedzialne za inne osoby - często członków swojej rodziny. Są przekonane, że nie zasługują na miłość, co wiąże się z ich niską samooceną. Często rezygnują z własnych potrzeb na rzecz innych osób. Pragną akceptacji przez innych, równocześnie mając problemy ze zwracaniem się o pomoc. Próbują dostosowywać się do ważnych dla siebie osób w celu zatrzymania ich przy sobie. Niechętnie formalizują związki, angażują się emocjonalnie i mają trudności w czerpaniu satysfakcji z bliskości fizycznej. Kłótnie postrzegają bardzo negatywnie, przez co uciekają od konfrontacji na rzecz innych stylów rozwiązywania konfliktów, np. unikania i dostosowania się, co wiąże się z tłumieniem złości i gniewu. Preferują wartości materialne, a nie te prospołeczne.

Jim Conway ${ }^{11}$ proponuje, aby dorosłe dzieci rozwodzących się rodziców próbowały - podobnie jak on sam - zmierzyć się z przeszłością. Wyróżnia etapy tego procesu adaptacyjnego, których przejście umożliwia powrót do normalnego życia i pozostawienia za sobą negatywnych przeżyć z okresu dzieciństwa. Podstawowe informacje na ten temat zebrano w tabeli 1.

B. M. Kaja, A. W. Wróblewska, Psychospołeczne funkcjonowanie dorosłych dzieci rozwiedzionych rodziców, [w:] Małżenstwo. Rodzina. Rozwód, red. B. M. Kaja, Bydgoszcz 2013, s. 151.

M. Beisert, Rozwód. Proces radzenia sobie z kryzysem, Poznań 2000, s. 123.

9. Merbert, Rozwód w rodzinie. Jak wesprzeć dzieci?, Gdańsk 2005, s. 10.

10 B. M. Kaja, A. W. Wróblewska, Psychospołeczne funkcjonowanie..., dz. cyt., s. 152.

11 J. Conway, Dorosłe dzieci rozwiedzionych rodziców. Jak uwolnić się od bolesnej przeszłości, przekł. W. Maj, Warszawa 1997, s. 145n. 
Tabela 1. Etapy ,uzdrowienia” DDRR według J. Conwaya

\begin{tabular}{|c|c|c|}
\hline Etap & O czym należy wiedzieć & $\begin{array}{c}\text { Co przeżywa } \\
\text { DDRR } \\
\text { w tej fazie }\end{array}$ \\
\hline $\begin{array}{l}\text { Postanowienie } \\
\text { o poddaniu się } \\
\text { leczeniu }\end{array}$ & $\begin{array}{l}\text { Należy sobie zdawać sprawę z tego, że DDRR czeka } \\
\text { wiele pracy, bólu i trudu. Czasami bywa tak, że stop- } \\
\text { niowo dojrzewa ono do decyzji o zerwaniu z prze- } \\
\text { szłością, a czasami zmuszają je do zmiany sytuacje } \\
\text { życiowe. Warto zastanowić się, jakie jest źródło wła- } \\
\text { snego lęku, gniewu, perfekcjonizmu, depresji itp. Czy } \\
\text { nie biorą one początku w domu rodzinnym? }\end{array}$ & $\begin{array}{l}\text { lęk, wstyd, } \\
\text { zakłopotanie, } \\
\text { niepokój, } \\
\text { niepewność, } \\
\text { nadzieję }\end{array}$ \\
\hline $\begin{array}{l}\text { Łączność } \\
\text { duchowa }\end{array}$ & $\begin{array}{l}\text { Ważny jest aspekt duchowy leczenia, czyli powrót do } \\
\text { Prawdy - Boga. DDRR powinno zastanowić się, czy } \\
\text { nie mściło się na Bogu i podejmowało próby powie- } \\
\text { dzenia Mu o swoim cierpieniu. Tworzenie bliskiej re- } \\
\text { lacji z Bogiem jest procesem, który pozwala uwolnić } \\
\text { się od przeszłości i pozytywnie wykorzystać kumulo- } \\
\text { waną energię. }\end{array}$ & $\begin{array}{l}\text { zadumę, } \\
\text { zaskoczenie, } \\
\text { żal, wyrzuty } \\
\text { sumienia, ulgę, } \\
\text { lęk, samotność } \\
\text { nadzieję }\end{array}$ \\
\hline $\begin{array}{l}\text { Uczestnictwo } \\
\text { w grupie } \\
\text { wsparcia }\end{array}$ & $\begin{array}{l}\text { Początkowo DDRR przeżywa lęk, który może pro- } \\
\text { wadzić zarówno do ucieczki, jak i agresji. Z czasem } \\
\text { może ono jednak nauczyć się dzielić swoimi proble- } \\
\text { mami z innymi osobami, które doświadczyły podob- } \\
\text { nych przeżyć. } \\
\text { Lęk przed wejściem w grupę wsparcia wynika z: } \\
\text { - przekonania, że DDRR samo sobie poradzi; } \\
\text { - lęku przed pojęciem ryzyka „ujawnienia się” } \\
\text { przed innymi; } \\
\text { - niechęci do rozdrapywania starych ran. } \\
\text { Wybrana grupa wsparcia powinna: } \\
\text { - walczyć o wspólną sprawę - pomóc DDRR; } \\
\text { - mieć właściwy cel - udzielać sobie wzajemnego } \\
\text { wsparcia w procesie radzenia sobie z traumatycz- } \\
\text { nymi doświadczeniami związanymi z rozwodem } \\
\text { rodziców; } \\
\text { - być zamknięta; } \\
\text { - posiadać odpowiednią strukturę. }\end{array}$ & $\begin{array}{l}\text { lęk inter- } \\
\text { personalny, } \\
\text { ulgę, złość, ból, } \\
\text { ufność }\end{array}$ \\
\hline $\begin{array}{l}\text { Wspominanie } \\
\text { przeszłości }\end{array}$ & $\begin{array}{l}\text { Powrót do wspomnień jest bolesny, dlatego warto } \\
\text { początkowo otwierać się przed zaufanymi osobami, } \\
\text { nie wszyscy bowiem mogą udźwignąć ciężar historii } \\
\text { o negatywnych doświadczeniach DDRR i właściwie } \\
\text { zareagować. Po „wyznaniu” DDRR odczuwa euforię, } \\
\text { ale jest to stan przejściowy, który przeminie. } \\
\text { Co może pomóc na tym etapie: } \\
\text { - opowiedzenie swojej historii; } \\
\text { - opisanie swojej historii; } \\
\text { - regresja kierowana pod kontrolą specjalisty; } \\
\text { - studiowanie literatury na temat wsparcia; } \\
\text { - doświadczenia życia codziennego. }\end{array}$ & $\begin{array}{l}\text { ból, cierpienie, } \\
\text { żal, lęk, gniew, } \\
\text { smutek, } \\
\text { rozgoryczenie, } \\
\text { radość, } \\
\text { euforię, ulgę }\end{array}$ \\
\hline
\end{tabular}




\begin{tabular}{|c|c|c|}
\hline Etap & O czym należy wiedzieć & $\begin{array}{c}\text { Co przeżywa } \\
\text { DDRR } \\
\text { w tej fazie } \\
\end{array}$ \\
\hline $\begin{array}{l}\text { Odżałowanie } \\
\text { straty }\end{array}$ & $\begin{array}{l}\text { DDRR jako osoba dorosła łatwiej poradzi sobie z ża- } \\
\text { lem. Na stratę może ono spojrzeć z innej perspekty- } \\
\text { wy. Pomoże mu to w budowaniu bliskich związków } \\
\text { oraz w nauce wyrażania emocji i współodczuwania. } \\
\text { Proces żałowania przebiega według następujących } \\
\text { etapów: } \\
\text { - wstrząs; } \\
\text { - zaprzeczanie; } \\
\text { - żal; } \\
\text { - integracja pozytywna (akceptacja straty umożli- } \\
\quad \text { wia ujawnienie mocnych cech podmiotu). }\end{array}$ & $\begin{array}{c}\text { smutek, żal, ból, } \\
\text { cierpienie, sa- } \\
\text { motność, od- } \\
\text { rzucenie }\end{array}$ \\
\hline $\begin{array}{l}\text { Odrzucenie } \\
\text { mentalności } \\
\text { ofiary }\end{array}$ & $\begin{array}{l}\text { DDRR często nabywają cech ofiar. Warto zatem zdia- } \\
\text { gnozować, czy samemu nie posiada się owych cech. } \\
\text { Pomoże w tym lista sporządzona przez J. Conwaya*. } \\
\text { Następnie trzeba podjąć decyzję o: niechęci do bycia } \\
\text { ofiarą, rozpoczęciu życia teraźniejszością i dla innych } \\
\text { ludzi oraz chęci odkrycia własnych uzależnień. }\end{array}$ & $\begin{array}{l}\text { lęk, ulgę, ra- } \\
\text { dość, nie- } \\
\text { pewność }\end{array}$ \\
\hline $\begin{array}{l}\text { Przebaczenie } \\
\text { przeszłości }\end{array}$ & $\begin{array}{l}\text { Przebaczenie jest procesem przebiegającym według } \\
\text { następujących etapów: } \\
\text { - przyznanie przed samym sobą, że wyrządzono } \\
\text { mi zło; } \\
\text { - odczucie rozdrażnienia i gniewu za to zło; } \\
\text { - odżałowanie tego, co zostało utracone; } \\
\text { - refleksja nad skutkami przebaczenia; } \\
\text { - ustalenie powodów przebaczenia danej osobie; } \\
\text { - udzielenie łaski przebaczenia; } \\
\text { - spotkanie z krzywdzicielem. } \\
\text { Przebaczenie eliminuje mechanizm obronny w po- } \\
\text { staci zaprzeczenia. Przebaczyć należy rodzicom oraz } \\
\text { samemu sobie. }\end{array}$ & $\begin{array}{l}\text { lęk, niepokój, } \\
\text { ulgę, radość, żal }\end{array}$ \\
\hline Praca nad sobą & $\begin{array}{l}\text { Na tym etapie należy ustalić osoby, które wesprą } \\
\text { DDRR w rozwiązywaniu poszczególnych problemów. } \\
\text { Konieczne jest przepracowanie swoich negatywnych } \\
\text { emocji. Z czasem warto próbować dzielić się swo- } \\
\text { imi pozytywnymi doświadczeniami z innymi ludźmi. } \\
\text { Możliwe jest spojrzenie na przeszłość z nowej per- } \\
\text { spektywy. }\end{array}$ & $\begin{array}{l}\text { spokój, ulgę, ra- } \\
\text { dość, lęk, nie- } \\
\text { pewność }\end{array}$ \\
\hline $\begin{array}{l}\text { Rozpoczęcie } \\
\text { nowego życia } \\
\text { i radowanie } \\
\text { się nim }\end{array}$ & $\begin{array}{l}\text { Na ostatnim już etapie każde DDRR powinno zadbać } \\
\text { o siebie: poszukać w sobie pozytywów, odpoczywać } \\
\text { i relaksować się, dbać o swoje ciało i umysł poprzez } \\
\text { odbudowę pozytywnych relacji z najbliższymi, roz- } \\
\text { wijać swoje zainteresowania oraz pomagać innym. }\end{array}$ & $\begin{array}{c}\text { radość, satys- } \\
\text { fakcję, poczucie } \\
\text { sukcesu i sensu } \\
\text { życia }\end{array}$ \\
\hline
\end{tabular}

* J. Conway, Dorosłe dzieci rozwiedzionych rodziców, dz. cyt., s. 218.

Źródło: J. Conway, Dorosłe dzieci rozwiedzionych rodziców. Jak uwolnić się od bolesnej przeszłości, Warszawa 1997, s. 145n. 


\section{Wsparcie dziecka w sytuacji rozwodu rodziców}

Zważywszy na wiele negatywnych skutków rozwodu rodziców dla dzieci, warto zastanowić się, w jaki sposób je wesprzeć, aby w możliwie najwyższym stopniu zminimalizować działanie destruktywnych czynników, hamujących ich rozwój.

Urszula Sokal ${ }^{12}$ dowodzi, że rodzice powinni starać się być obiektywni w trakcie rozwodu, gdyż pomoże to ich dzieciom uzyskać bardziej jednolity obraz rzeczywistości. ,Jasność co do przyczyn rozwodu rodziców wśród dzieci okazała się jednoznacznie związana z lepszym poziomem ich funkcjonowania psychospołecznego, wyższym poziomem samooceny i satysfakcji z życia, a także niższym tłumienia depresji”"13. Dlatego tak istotne jest informowanie dzieci o wszelkich poczynaniach rodziców, o ich decyzjach i wątpliwościach, które w przyszłości zaważą na życiu wszystkich członków rodziny. Wysoki poziom wiedzy zapobiega bowiem lękom wynikającym z wyimaginowanej, opartej na niewiedzy, projekcji sytuacji rozwodowej. Stąd też wynika potrzeba umiejętnego prowadzenia rozmowy z dziećmi na temat rozwodu. Judith Wallerstein oraz Sandra Blakeslee $^{14}$ udzielają konkretnych wskazówek dotyczących sposobu przekazywania dzieciom informacji o rozstaniu rodziców (tabela 2).

W modelu Gary'ego W. Petersona zapewnienie rodzicom wsparcia, ograniczenie przymusu wobec dzieci oraz konsekwencja w postępowaniu warunkują rozwijanie kompetencji społecznych dzieci (samoakceptacji, umiejętności współpracy, kontroli wewnętrznej itp.), których wysoki poziom sprzyja radzeniu sobie przez nie z sytuacją rozwodową rodziców ${ }^{15}$. Czynnikami, które w znacznym stopniu mogą pomóc łagodniej przejść dziecku przez tę traumatyczną sytuację, są: wsparcie społeczne ze strony innych osób, kompetencje własne dziecka, a także zdolności rodziców, wśród których znajdują się: zaradność, umiejętność nawiązywania nowych związków społecznych, wysoki poziom wykształcenia, znaczący dochód, dojrzałość emocjonalna, nietradycyjne postawy wobec ról przypisywanych płci oraz zdolność identyfikacji nagradzających aspektów nowych ról ${ }^{16}$. W praktyce oznacza to, że rodzice winni dbać

12 B. M. Kaja, A. W. Wróblewska, Psychospołeczne funkcjonowanie..., dz. cyt., s. 151.

13 Tamże, s. 178.

14 J. Wallerstein, S. Blakeslee, Rozwód, a co z dziećmi?, przekł. E. Urbański, Poznań 2005, s. 36n.

15 E. M. Hetherington, M. Cox, R. Cox, The aftermath of divorce, [w:] Mother-Child, Father-Child Relations. National Association for the Education of Young Children, eds. J. H. Stevens Jr., M. Matthews, Washington, D. C. 1978, s. 110-155, za: E. Wideł, Wpływ rozwodu na psychospołeczny rozwój dziecka - model Petersena, ,Problemy Rodziny” 3 (1995), s. 32-33.

16 W. J. Goode, After Divorce, New York 1956; B. L. Bloom, S. W. White, S. J. Asher, Marital disruption as a stressor: a review and analysis, „Psychological Bulletin” 83 (1978), s. 867-894, za: E. Wideł, Wpływ rozwodu ..., dz. cyt., s. 34. 
Tabela 2. Jak przekazywać dziecku informację o rozstaniu rodziców - wskazówki praktyczne

\section{Zasady rozmowy o rozstaniu rodziców}

W czasie pierwszej rozmowy rodzic powinien po-

starać się:

- wyjaśnić dziecku, że wraz z drugim małżonkiem zdecydowali się rozstać i co to będzie dla niego oznaczało;

- powtarzać, że dziecko jest dla niego bardzo ważne;

- mówić prostymi słowami;

- mówić spokojnie;

- wybrać chwilę spokoju, kiedy ma możliwość przebywania z dzieckiem przez dłuższy czas;

- przeprowadzić tę rozmowę w obecności partnera;

- być otwarty i szczery;

- okazywać swoje prawdziwe emocje;

- wyjaśnić, dlaczego postanowili się rozstać;

- opowiedzieć o pięknych chwilach w małżeństwie i ważnym w nim miejscu dziecka;

- chronić własny wizerunek i poczucie własnej wartości;

- mówić o tym, jak przestało układać się w małżeństwie i krótko o przyczynach tej sytuacji;

- powiedzieć o próbie ratowania związku przez rodziców;

- pozwalać dziecku wyrazić swoje emocje;

- zapewnić dziecko, że to nie jego wina;

- wyjaśnić, że rozwód jest próbą naprawy czegoś oraz że rodzina będzie istniała nadal - tylko inna od dotychczasowej;

- pozwalać dziecku na wyciąganie własnych wniosków;

- odwołać się do doświadczeń jego rówieśników, których rodzice się rozwiedli;

- zachęcać dziecko do mówienia o swoich obawach;

- dowiedzieć się, co myśli dziecko;

- uwzględniać sugestie dziecka;

- obiecać, że będzie uwzględniać potrzeby dziecka;

- zapewnić o wsparciu;

- powiedzieć, że ta sytuacja jest trudna dla niego samego ;

- obiecać powrót do rozmowy o rozwodzie;

- nie wyrażać gniewu wobec partnera;

- nie obwiniać partnera;

- nie przeciągać dziecka na swoją stronę.

Źródło: opracowanie własne na podstawie: J. S. Wallerstein, S. Blakeslee, Rozwód, a co zdziećmi?, przekł. E. Urbański, Poznań 2005, s. 36-47.
W czasie drugiej rozmowy rodzic powinien pamiętać o:

- przypomnieniu, co było treścią pierwszego spotkania;

- upewnieniu się, co dziecko wie, co pamięta $\mathrm{z}$ wcześniejszej rozmowy;

- ustaleniu planów na przyszłość;

- przekazaniu swoich decyzji związanych z rozwodem;

- pokazaniu dziecku, że panuje nad sytuacją;

- uwzględnianiu potrzeb i oczekiwań dziecka;

- ofiarowaniu dziecku czasu na zadawanie pytań i dyskusję;

- szczerym udzielaniu odpowiedzi na pytania dziecka. 
o siebie samych chociażby poprzez rozwijanie swoich kompetencji, co przełoży się na ich mniejszą podatność na stres związany z rozwodem oraz mniejsze straty „rozwodowe” ponoszone przez ich dzieci.

Według Ewy Muszyńskiej ${ }^{17}$ skutki rozwodu można nieco złagodzić dzięki otoczeniu dziecka odpowiednią opieką psychopedagogiczną, nieograniczającą się jednak tylko i wyłącznie do jego wsparcia w środowisku rodzinnym. Silne, negatywne emocje towarzyszące mu podczas rozpadu rodziny warunkują również jego sytuację szkolną. Zainicjowane działania powinny zmierzać do przywrócenia dziecku utraconej równowagi psychofizycznej. Szczególnie ważna jest udzielona mu pomoc w zrozumieniu istoty rozwodu, zwłaszcza w momencie, gdy dowiaduje się ono o rozpadzie związku rodziców. Psycholodzy i pedagodzy zobligowani są do rzetelnego zdiagnozowania sytuacji dziecka oraz jego poziomu przystosowania społecznego, a następnie zaaranżowania kompleksowych działań o charakterze socjoterapeutycznym, kompensacyjno-korekcyjnym, dobranych do jego indywidualnych potrzeb i możliwości. Pomocny może okazać się trening empatii, dzięki któremu dziecko doskonali swoją umiejętność dostrzegania różnych punktów widzenia sytuacji rozwodowej ${ }^{18}$. Istotnym wsparciem może okazać się również odpowiednie zorganizowanie dziecku zajęć pozalekcyjnych, wypełniających jego czas wolny, umożliwiających mu chwilową ucieczkę od problemów rodzinnych ${ }^{19}$. Marzanna Farnicka ${ }^{20}$ zwraca uwagę na konieczność wspierania dziecka przez członków grupy rówieśniczej, którzy pomagają mu przystosować się społecznie dzięki nauce umiejętności społecznych, przyczyniających się do sprawniejszego radzenia sobie przez niego z trudną sytuacją.

Dzieci zmagające się z rozwodem rodziców (niezależnie od wieku) oczekują odpowiedniego wsparcia, które Judith Wallerstein sprowadza do: ${ }^{21}$

- szczerych rozmów z dzieckiem o tym, co się dzieje w rodzinie;

- współuczestnictwa w kreowaniu nowych zadań dla dziecka;

- rozmów o przyszłości dziecka - jego oczekiwaniach wobec rodziców;

- angażowania dziecka w zadania związane ze szkołą i grupą rówieśniczą;

- dostarczania dziecku pozytywnych wrażeń płynących z wykonywania przez nie zadań, którymi się pasjonuje;

- pomocy dziecku w rozwijaniu jego zainteresowań;

17 E. Muszyńska, Diagnoza i pomoc $w$ rozwiązywaniu indywidualnych problemów uczniów, [w:] Psychologia rozwiązywania problemów szkoły, red. J. Miluska, Poznań 2001, s. 338-342.

18 M. Farnicka, Jak sobie poradzić z rozwodem rodziców (według koncepcji Wallerstein), „Problemy Rodziny” 2-3 (1999), s. 71.

19 E. Muszyńska, Diagnoza i pomoc.., dz. cyt., s. 338n.

20 M. Farnicka, Jak sobie poradzić..., dz. cyt., s. 71.

21 M. Farnicka, Sposoby radzenia..., dz. cyt., s. 19-22. 
- wyjaśnienia dziecku nowych zadań wynikających z zaistniałej sytuacji rodzinnej;

- dbałości o pozytywne relacje z obojgiem rodziców;

- zapewnienia dziecku poczucia bezpieczeństwa;

- rozmów o miłości do niego;

- okazywania wsparcia;

- wzmacniania jego samooceny (np. przez pochwały);

- aranżowania działań, w których dziecko będzie odnosiło sukces;

- nauki dziecka wyrażania emocji w sposób konstruktywny i autentyczny;

- okazywania dziecku miłości przez obojga rodziców;

- nauki asertywności;

- pomocy dziecku przebaczania rodzicowi, który odszedł z domu;

- rozmów z dzieckiem na temat skutków rozwodu;

- wspólnego planowania przyszłości bez obecności jednego rodzica;

- rozmów z dzieckiem na temat powszechności zjawiska rozwodu;

- rozmów na temat miłości, szacunku, bliskości i bycia w związku.

\section{Mediacje rodzinne jako jedna z propozycji pomocy dziecku i rodzinie}

Mediacja najczęściej definiowana jest jako konstruktywna metoda rozwiązywania konfliktów, podczas której strony podejmują dialog i w obecności pośrednika wypracowują satysfakcjonujące je rozwiązania ${ }^{22}$. Można ją zatem traktować jako formę pomocy osobom znajdującym się w trudnej sytuacji, godną zastosowania w sytuacjach konfliktów rodzinnych, z których najbardziej zaogniony jest rozwód.

Rozmowa prowadzona ze skonfliktowanymi osobami zmierza do rozwiązania ważnych kwestii, wśród których znajdują się te dotyczące dzieci. Samo ustalenie sposobu rozstania rodziców może zatrzymać eskalację konfliktu między małżonkami. Nie próbują oni wtedy podczas - kilkuletnich nawet - postępowań sądowych udowadniać sobie winy za rozpad związku. Zapobiegają tym samym wielu sytuacjom stresującym zarówno dla siebie samych, jak i dla dzieci . Inne kwestie rozwiązywane podczas spotkań mediacyjnych, takie jak ustalanie: władzy rodzicielskiej, miejsca zamieszkania dzieci, kontaktów dzieci z rodzicem, który nie będzie sprawował bezpośredniej opieki nad nimi, a nawet wysokości alimentów, przekładają się na jakość kontaktów między małżonka-

22 A. Lewicka-Zelent, Uwarunkowania poziomu gotowości nieletnich do zadośćuczynienia w paradygmacie sprawiedliwości naprawczej, wyd. 2, Lublin 2013, s. 99. 
mi i dziećmi. Nie podejmują oni otwartej walki o zaspokojenie swoich potrzeb, gdyż na drodze kompromisu, poszukując twórczych rozwiązań, próbują zadowolić wszystkich członków rodziny ${ }^{23}$.

Występują jednak pewne przeciwwskazania do rozwiązywania konfliktów rodzinnych podczas spotkań mediacyjnych. Według mediatorów ze Stowarzyszenia Mediatorów Rodzinnych ${ }^{24}$ pośrednik nie spełni swojej roli w przypadku, gdy rodzic stosuje przemoc, jest uzależniony lub chory psychicznie - nie może podejmować świadomych decyzji. Rozwodzący się rodzic doświadcza bardzo silnych negatywnych emocji, które subiektywnie są ,zbyt świeże”, aby mógł poszukiwać racjonalnego rozwiązania konfliktu. Mediacja traci sens również w przypadku, gdy strony przystępują do niej z chęci uzyskania korzyści dla siebie. Dlatego tak ważny jest odpowiedni dobór właściwej formy pomocy w przypadku konkretnej rodziny. Niemniej jednak strony, które wyrażają chęć uczestniczenia w mediacji rodzinnej, mogą czerpać z niej wiele korzyści. Podczas spotkań pośrednik pomaga im uświadomić potrzeby ich dzieci. Stymuluje on proces podejmowania decyzji w sposób świadomy i przemyślany - na podstawie dokonanej analizy korzyści i wad różnych sposobów sprawowania opieki nad dziećmi. Służy temu przede wszystkim przygotowanie planu opieki rodzicielskiej, w którym ujmuje się różnorakie kwestie związane z relacjami dzieci z ojcem i matką ${ }^{25}$. „Dzięki udziałowi w mediacji stronom stwarza się możliwość nie tylko odbudowania komunikacji, która pod wpływem sytuacji, w jakiej znajdują się strony w trakcie rozwodu, może zostać niejednokrotnie zachwiana w sposób trwały. Lecz także może wpłynąć na relacje między nimi, co jest istotne w przypadku małżeństw, które mają dzieci”26.

Mediacja przynosi dzieciom rozwodzących się rodziców wiele korzyści. Podejmujący dialog rodzice przyczyniają się do zwiększenia poczucia ich stabilizacji, bezpieczeństwa oraz wiary w możliwość utrzymywania kontaktów z obojgiem. Rodzice mają okazję lepiej uświadomić sobie, jakie problemy ma ich dziecko w związku z zaistniałą sytuacją rozwodową i jakie czekają je zmiany życiowe ${ }^{27}$. Podczas mediacji zachowywana jest zasada dobra dziecka, którą respektuje się m.in. poprzez ograniczanie negatywnych emocji u dzieci czy włą-

23 Mediacje rodzinne $w$ praktyce. Poradnik, red. Pracownicy ROPS w Krakowie i Mediatorzy Stowarzyszenia Mediatorów Rodzinnych w Warszawie, Kraków 2008, s. 5-6.

${ }_{24}$ Gdy rodzina się rozpada: potrzeby, decyzje, rozwiązania, red. R. Milewski, Warszawa 2006, s. 20.

25 Tamże, s. 20.

26 D. Bara, Mediacja forma rozwiązania konfliktu małżeńskiego powstałego w sytuacji rozwodowej, [w:] Rodzina. Powołanie - zadania - zagrożenia, red J. Zimny, Stalowa Wola 2014, s. 364.

27 H. Przybyła-Basista, Mediacje rodzinne - wybrane zagadnienia, http://www.mediacerodzina.pl (15.05.2015). 
czanie ich w pewne etapy spotkań mediacyjnych, co przyczynia się do zwiększenia ich wiedzy o sytuacji, w jakiej znalazła się ich rodzina i one same, oraz obniżenia poziomu lęku wynikającego z niewiedzy. Mogą one poczuć się traktowane podmiotowo dzięki możliwości wypowiedzenia się w kwestiach dotyczących ich emocji i potrzeb $^{28}$.

\section{Bajki terapeutyczne dla dzieci rozwodzacych się rodziców}

Dziecko znajdujące się w sytuacji rozwodu rodziców przeżywa przede wszystkim lęk o własny los, w którego redukcji niezwykle pomocne okazuje się czytanie lub opowiadanie bajek - głównie terapeutycznych, które oddziałują na sfery poznawczą, emocjonalną oraz społeczną 29.

W literaturze psychopedagogicznej bajka terapeutyczna definiowana jest jako utwór skierowany do dzieci w wieku od 4 do 9 lat. Przyjmuje on formę opowiadania fantastycznego, zawierającego fabułę, która w swojej strukturze posiada elementy redukujące lęk. Najważniejszym jej celem jest wyciszenie dziecka, zmniejszenie liczby jego problemów emocjonalnych oraz wspieranie rozwoju osobistego ${ }^{30}$.

Dziecko znajdujące się w sytuacji rozwodu rodziców często czuje się niezrozumiane, samotne i niepotrzebne. Dzięki wsparciu informacyjnemu czy duchowemu bohatera bajki - w procesie identyfikacji -otrzymuje pośrednio pomoc, zrozumienie i przyjaźń. Czasami przejmuje pewne cechy bohatera. Dlatego utożsamienie się z nim przyspiesza rozwój procesów poznawczych dziecka, głównie wyobraźni, oraz nawiązanie fikcyjnej przyjaźni z postacią bajkową ${ }^{31}$.

Dziecko rozwodzących się rodziców często posiada deficyty kompetencji społecznych. Niechętnie podejmuje nowe czynności. Staje się mniej wrażliwe na potrzeby innych ludzi. Jednak sytuacje przedstawione w bajkach rozwijają empatię i pomagają mu rozumieć siebie i innych oraz motywować do udzielenia pomocy ludziom jej potrzebującym ${ }^{32}$.

Zdarza się też, że dziecko przejmuje odpowiedzialność za zaistniałą sytuację lub obarcza nią jednego rodzica. Próbuje interpretować rozwód jako reakcję ro-

\footnotetext{
${ }^{28}$ www.smr.org.pl/mediacje/dba\%C5\%82o\%C5\%9B\%C4\%87-o-dobro-dzieci-wmediacji (15.05.2015).

29 M. Molicka, Bajkoterapia. O lękach dzieci i nowej metodzie terapii, Poznań 2002, s. 25.

30 Tamże, s. 153.

31 Tamże, s. 153-154.

32 Tamże, s. 170-175.
} 
dziców na swoje naganne zachowanie. Nie potrafi odnaleźć się w zaistniałej sytuacji oraz znaleźć odpowiedniego rozwiązania problemu. Dzięki poznaniu losu bohaterów bajek może zrozumieć, że także inni ludzie mają kłopoty. Dowiaduje się, w jaki sposób może pokonać trudności związane z nową sytuacją rodzinną ${ }^{33}$.

Ponadto dziecko rozwodzących się rodziców często nie ma zaspokojonych podstawowych potrzeb: bezpieczeństwa, miłości oraz akceptacji. Traci ono poczucie bezpieczeństwa i stabilizacji przede wszystkim z tego powodu, że jeden z rodziców nie jest obecny w domu na co dzień, a jedynie od święta. Poprzez bajkę ma okazję doświadczyć pozytywnej, wypełnionej ciepłem atmosfery. Odnajduje przyjaciół w gronie bajkowych postaci, które zawsze są do jego dyspozycji. Dziecko przejawia lęk przed porzuceniem i odrzuceniem. Boi się, że zostanie samo, a jego rodzice założą nowe rodziny i będą mieli kolejne dzieci, skutkiem czego będzie ono zaniedbane zarówno w sferze materialnej, jak i emocjonalnej. W takiej sytuacji funkcja bajki sprowadza się do upewnienia go, że podobnie jak fikcyjny bohater zasługuje na miłość rodziców ${ }^{34}$.

Deprywacja potrzeby akceptacji u dzieci rozwodzących się rodziców najczęściej skutkuje niskim poziomem poczucia własnej wartości, któremu towarzyszy silne poczucie odrzucenia. W takiej sytuacji bohater bajki może stanowić dla dziecka wzór osobowy. Pokonuje on bowiem w swoim życiu różne przeszkody, a w rezultacie osiąga zakładany cel, dzięki czemu jest podziwiany, akceptowany oraz darzony szacunkiem ${ }^{35}$.

\section{Próbka badań własnych}

Wśród osób badanych znalazły się podopieczne kuratorów rodzinnych - matki w wieku od 35 do 40 lat z orzeczonym rozwodem oraz ograniczoną władzą rodzicielską nad dziećmi poniżej 10. roku życia. W chwili badania tylko jedna spośród badanych kobiet pracowała, natomiast pozostałe posiadały status osób bezrobotnych, korzystających ze wsparcia MOPR. Kobiety były po rozwodzie od 2 do 8 lat.

Wszystkie matki, które przeczytały bajki terapeutyczne ${ }^{36}$ o dzieciach, których rodzice się rozstali, podkreśliły, że dotyczą one realnej sytuacji zwykłych

33 W. Szulc, Arteterapia. Narodziny idei, ewolucja teorii, rozwój praktyki, Warszawa 2011, s. 137.

34 M. Molicka, Bajkoterapia. O lękach dzieci i nowej metodzie terapii, Poznań 2002, S. 154 .

35 Tamże, s.154.

36 Dziecko a rozwód. Bajki terapeutyczne dla dzieci rozwodzacych się rodziców, red. A. Lewicka-Zelent, K. Korona, Warszawa 2015. 
ludzi i przeciętnej rodziny. Ich wypowiedzi świadczą o tym, że utożsamiają się one z bajkowymi postaciami, które tak jak one mierzyły się z rozwodem. Głównej funkcji bajek upatrują w jej uspokajającym i informacyjnym charakterze. Według nich specyficzny klimat oraz przekazywanie dziecku podstawowych informacji o sytuacji rozwodowej sprzyjają zwiększeniu jego poczucia bezpieczeństwa ${ }^{37}$.

Jedna z matek próbowała przyjąć perspektywę dziecka, którego rodzice postanowili się rozstać. Twierdziła, że bajka terapeutyczna umożliwia jej zrozumienie tej nowej sytuacji rodzinnej. Zaskakuje jednak, że nie przenosi ona tej fikcyjnej - aczkolwiek prawdopodobnej - sytuacji na życie swojego dziecka, które również doświadczyło rozwodu rodziców. Trudno jednak stwierdzić, czy świadczy to o minimalizowaniu skutków rozwodu we własnej rodzinie.

Dwie matki uznały, że bajki zakończyły się szczęśliwie. Obiektywnie trudno jednak przyznać, że rozpad rodziny i wychowywanie dziecka przez jednego rodzica jest pożądaną sytuacją. Niemniej jednak można przypuszczać, że badane kobiety doceniły to, że zarówno matka, jak i ojciec utrzymują dobre relacje ze swoim dzieckiem i współuczestniczą w jego wychowaniu.

Dzieci badanych matek przeczytały te same bajki, a następnie wypowiedziały się na ich temat. Stwierdziły, że przedstawiona w nich sytuacja jest pożądana w kontekście zachowania rodziców po rozwodzie. Odbierały opisywane historie jako smutne z uwagi na doświadczany przez główną bohaterkę bajek rozwód rodziców. Niemniej jednak zakończenie serii przygód swojej bajkowej rówieśniczki uznały za pomyślne. Były zadowolone, że dziecko, którego rodzice się rozstali, nadal utrzymywało dobry kontakt z obojgiem z nich. Pomimo że małżonkowie nie mieszkali razem, zajmowali się dzieckiem i wspierali je.

Dzieci podkreśliły, że dziewczynka odczuwała miłość mamy i taty, a odejście rodzica $\mathrm{z}$ domu nie oznaczało odrzucenia emocjonalnego. Jedno z nich zwróciło również uwagę, że bohaterka bajki odczuwała poczucie winy z powodu rozstania rodziców. Poziom tego poczucia winy obniżyły rozmowy z nimi. Dlatego tak istotne okazało się dla rodziców umiejętne przeprowadzenie dialogu z dzieckiem, mającego na celu wyjaśnienie wszelkich jego wątpliwości związanych z rozwodem. Wydaje się jednak, że w przypadku 9-letniej Marleny stanowiło to tylko ,pobożne życzenie”. Pisze ona bowiem, że wysłuchałaby rodziców, gdyby dostała taką szansę.

Reasumując należy stwierdzić, że nie sam rozwód, a jego zakończenie i ,,poukładanie" spraw między członkami rodziny ma największe znaczenie dla dzieci. s. 153.

37 M. Molicka, Bajkoterapia. O lękach dzieci i nowej metodzie terapii, Poznań 2002, 


\section{Przykładowe wypowiedzi matek na temat bajek terapeutycznych}

Pani Monika: „Bajka opowiadała o rzeczywistej sytuacji, jak dla mnie była bardzo uspokajająca".

Pani Agnieszka: „Bajeczka bardzo fajna, taka spokojna, bardzo fajna historyjka, opowiadała o zwykłych ludziach, takich jak my sami. Bardzo przyjemnie się czytało. Zakończyła się bardzo fajnie, szczęśliwie”.

Pani Anna: ,Jak dla mnie fajna bajka, opowiadała o sytuacji dziecka, które dowiedziało się o rozstaniu rodziców. Skończyła się pomyślnie. Gdybym była dzieckiem czytającym tą bajkę i znajdowała się w takiej sytuacji, martwiłabym się mniej i inaczej interpretowałabym sytuację, w której się znalazłam”.

Pani Andżelika: „Szczerze mówiąc, bajka ta przedstawia życie codzienne ludzi w sytuacji, gdy informują dziecko o swoim rozstaniu, jednak zawiera w sobie zaskakujące elementy, zwierzęta jako postaci, w tym przypadku pandy. Rodzice dokładnie tłumaczyli dzieciom sytuację, dawali wsparcie i poczucie bezpieczeństwa, co moim zdaniem jest najważniejsze”.

\section{Przykładowe wypowiedzi dzieci na temat bajek terapeutycznych}

Krystian, 9 lat: „Bajka była smutna, opowiadała o sytuacji, gdy małe dziecko dowiadywało się o rozstaniu rodziców, było smutne, zrozpaczone, jednak mama i tata mimo że nie mieszkali ze sobą, zajmowali się dzieckiem”.

Ewa, 7 lat: „Bajeczka podobała mi się dlatego, że wszystko się dobrze skończyło, dziewczynka miała mamusię i tatusia, mimo że tata nie mieszkał już z mamą".

Patrycja, 8 lat: „Bardzo podoba mi się ta bajka, dlatego że mimo sytuacji, w której tata odchodzi z domu, panda nie została sama, miała kochającą mamę i tatę. Na początku myślała, że to z jej winy rodzice się rozstają, ale później rodzice wytłumaczyli jej, że to nie jej wina”.

Daniel, 7 lat: ,„Podobała mi się ta bajka dlatego, że na początku była smutna, a później skończyła się radośnie. A dziewczynka miała oboje rodziców”.

Marlena, 9 lat: „Bardzo podobała mi się ta bajka, ponieważ kocham pandy, i na jej miejscu zachowałabym się tak samo. Wysłuchałabym rodziców i zrozumiała to, że tak musi być, i że to, że tata będzie mieszkał oddzielnie, nie oznacza, że mnie nie kocha. Bo nigdy tak nie będzie". 


\section{Zamiast zakończenia}

Wielu specjalistów pracujących z dziećmi, które doświadczają lub doświadczyły rozwodu rodziców, zastanawia się, w jaki sposób im pomóc. Na podstawie przeglądu literatury oraz własnych przemyśleń i doświadczeń związanych z prowadzeniem mediacji rodzinnych sformułowano pewne zalecenia i przeciwwskazania w postępowaniu z dziećmi ${ }^{38}$.

\section{Co moga zrobić rodzice, aby pomóc dzieciom} poradzić sobie z ich rozstaniem

- motywować je do rozmowy o uczuciach, faktach i potrzebach;

- przeprowadzić wstępną diagnozę ich funkcjonowania, chociażby przez obserwację podczas zabawy;

- wspierać indywidualnie;

- szukać wsparcia u osób najbliższych rodzinie;

- wyrażać otwarcie swoje uczucia;

- normalizować uczucia i zachowania dzieci, tzn. upewniać je, że mają prawo do takich, a nie innych emocji i reakcji, że są one naturalne w tak trudnej sytuacji;

- pozwalać mówić im o pozytywnych i negatywnych doświadczeniach rodzinnych;

- słuchać je uważnie i empatyzować z nimi;

- zachęcać do kontaktu z drugim rodzicem, wykorzystując pocztę tradycyjną i internetową;

- zwracać uwagę na zmianę ich zachowania;

- szanować ich prywatność i intymność, np. dzięki stworzeniu kącika samotności;

- podarować im swój czas;

- szczerze informować je o sytuacji rodzinnej;

- uczestniczyć w ważnych dla dziecka wydarzeniach;

- przedkładać dobro dzieci nad swoje własne;

- pamiętać, że rola małżonka kończy się, ale rola rodzica trwa nadal;

- przekazywać na bieżąco prawdziwe informacje o rozwodzie;

- przygotować dzieci na ,,nowe jutro”, powiedzieć im, co je czeka;

38 M. Beisert, Rozwód..., dz.cyt., 134n., M. Herbert, Rozwód..., dz.cyt., s. 22n., J. S. Wallerstein, S. Blakeslee, Rozwód..., dz. cyt., s. 94, R. Grochocińska, Psychospołeczna sytuacja dzieci w rodzinach rozbitych, Gdańsk 1990, s. 45. 
- zapytać dzieci o ich potrzeby przed ustalaniem kwestii rozwodowych (pozwolić wyrazić im swoje pragnienia);

- zapewniać, że są kochane;

- wychowywać, okazując: ciepło, wsparcie, stanowczość i konsekwencję;

- zachowywać się tak, aby dzieci mogły ich naśladować;

- zadbać o siebie i o odzyskanie własnej równowagi;

- być dla dzieci autorytetem (nie odbierać sobie wzajemnie tego zaszczytu);

- otoczyć dzieci szczególną opieką jeszcze przed rozwodem.

Czego nie moga robić rodzice, aby nie nasilać cierpienia swoich dzieci

- odbierać dzieciom prawa do: płaczu, smutku i żalu;

- mówić im, co powinny czuć;

- pocieszać słownie, gdy nie wiąże się z tym konkretne działanie;

- ukrywać swoich uczuć przed dziećmi;

- ukrywać prawdy o rozstaniu;

- zabraniać kontaktu z eksmałżonkiem;

- zmuszać dzieci do opowiadania się po stronie jednego rodzica;

- przerzucać odpowiedzialności na dzieci;

- umacniać ich poczucia winy ${ }^{39}$.

\section{Bibliografia}

Bara D., Mediacja formą rozwiązania konfliktu małżeńskiego powstałego w sytuacji rozwodowej, [w:] Rodzina. Powołanie - zadania - zagrożenia, red. J. Zimny, Stalowa Wola 2014, s. 357-366.

Beisert M., Rozwód. Proces radzenia sobie z kryzysem, Poznań 2000.

Conway J., Dorosłe dzieci rozwiedzionych rodziców. Jak uwolnić się od bolesnej przeszłości, przekł. W. Maj, Warszawa 1997.

Dziecko a rozwód. Bajki terapeutyczne dla dzieci rozwodzacych się rodziców, red. A. Lewicka-Zelent, K. Korona, Warszawa 2015.

Farnicka M., Jak sobie poradzić z rozwodem rodziców (według koncepcji Wallerstein), „Problemy Rodziny" 2-3 (1999), s. 67-71.

39 Na temat wspierania dzieci w trakcie rozwodu rodziców Czytelnik znajdzie więcej informacji w pozycji: L. R. Reynolds, Pomóż dziecku przetrwać rozwód. Poradnik dla rozwodzących się rodziców, Warszawa 2012. 
Farnicka M., Sposoby radzenia sobie z rozwodem przez dzieci, „Wychowanie na co Dzień” 3 (2000), s. 19-22.

Gdy rodzina się rozpada: potrzeby, decyzje, rozwiązania, red. R. Milewski, Warszawa 2006.

Grochocińska R.. Psychospołeczna sytuacja dzieci w rodzinach rozbitych, Gdańsk 1990.

Herbert M., Rozwód w rodzinie. Jak wesprzeć dzieci?, Gdańsk 2005.

Izdebska H., Wyższość rodzinny nad innymi środowiskami wychowawczymi, „Problemy Opiekuńczo-Wychowawcze" 1 (1989), s. 2-9.

Kaja B. M., Wróblewska A. W., Psychospołeczne funkcjonowanie dorosłych dzieci rozwiedzionych rodziców, [w:] Małżeństwo. Rodzina. Rozwód, red. B. M. Kaja, Bydgoszcz 2013, s. 147-186.

Lewicka-Zelent A., Uwarunkowania poziomu gotowości nieletnich do zadośćuczynienia w paradygmacie sprawiedliwości naprawczej, Lublin 2015.

Mediacje rodzinne w praktyce. Poradnik, red. Pracownicy ROPS w Krakowie i Mediatorzy Stowarzyszenia Mediatorów Rodzinnych w Warszawie, Kraków 2008.

Molicka M., Bajkoterapia. O lękach dzieci i nowej metodzie terapii, Poznań 2002.

Muszyńska E., Diagnoza i pomoc w rozwiązywaniu indywidualnych problemów uczniów, [w:] Psychologia rozwiązywania problemów szkoły, red. J. Miluska, Poznań 2001, s. 338-342.

Okoń W., Nowy słownik pedagogiczny, Warszawa 1998.

Przybyła-Basista H., Mediacje rodzinne - wybrane zagadnienia, http://mediacje-rodzina.pl (15.05.2015).

Reynolds L. R., Pomóż dziecku przetrwać rozwód. Poradnik dla rozwodzących się rodziców, Warszawa 2012.

Szulc W., Arteterapia. Narodziny idei, ewolucja teorii, rozwój praktyki, Warszawa 2011.

Wallerstein J., Blakeslee S., Rozwód, a co z dziećmi?, przekł. E. Urbański, Poznań 2005.

Wideł E., Wplyw rozwodu na psychospołeczny rozwój dziecka - model Petersena, „Problemy Rodziny" 3 (1995), s. 31-34.

Wilk J., Pedagogika rodziny. Zagadnienia wybrane, Lublin 2002.

Zaborowski Z., O rodzinie. Rodzina jako grupa społeczno-wychowawcza, Warszawa 1969.

Ziemska M., Rodzina a obecność, Warszawa 1977.

\section{Wykaz stron internetowych}

http://smr.org.pl/mediacje/dba\%C5\%82o\%C5\%9B\%C4\%87-o-dobro-dzieci-w-mediacji (15.05.2015). 